\title{
THE DEVELOPMENT OF STORY BOOK "IKAN SAKTI SUNGAI JANIAH" AS A LEARNING RESOURCE OF LITERATURE AT ELEMENTARY SCHOOL
}

\author{
Suci Amalia ${ }^{1}$, Gustimal Witri ${ }^{2}$ \\ 1,2 Universitas Riau, Pekanbaru, Indonesia \\ 1'suciiamaliaa10@gmail.com, ${ }^{2}$ gustimalw@yahoo.com
}

\begin{abstract}
This research aims at developing folklore story book of "Ikan Sakti Sungai Janiah" and finding out its feasibility. The story book was designed by using coreldraw7. Model 4D was used as the research method by using four stages; those are define, design, develop and dessiminate, but it was only limited until the third stage. The data of this research was taken from a valid design-expert-instrument, a valid language-expert-instrument and students' responses. The data was a quantitative data which was measured by using guideline citeria for assessment categories in determining the quality of the product. The research findings based on a design expert on draft 1 with average percentage of $81.4 \%$ with feasible category considered improved on draft 2 to $96 \%$ with highly feasible category. Furthermore, based on a language expert on draft 1 with the average percentage 68.75\% with feasible category, it was considered improved on draft 2 to $95 \%$ with highly feasible category. For students' responses, the average percentage was $94.5 \%$ with highly feasible category. Based on the result of the research, it can be concluded that the product developed by the researcher was considered very proper to use as a learning source of literature at primary school.
\end{abstract}

Keywords: picture book, learning resources, elementary school

\section{PENGEMBANGAN BUKU BERGAMBAR CERITA RAKYAT "IKAN SAKTI SUNGAI JANIAH" SEBAGAI SUMBER BELAJAR PEMBELAJARAN SASTRA DI SEKOLAH DASAR}

\begin{abstract}
ABSTRAK
Penelitian ini bertujuan untuk mengembangkan buku bergambar cerita rakyat "Ikan Sakti Sungai Janiah" dan mengetahui kelayakan buku bergambar cerita rakyat "Ikan Sakti Sungai Janiah" tersebut. Produk buku cerita bergambar ini dibuat menggunakan aplikasi coreldraw7. Metode penelitian yang digunakan adalah model 4D dengan empat tahapan yaitu tahap define (pendefinisian), tahap design (perancangan), tahap develop (pengembangan), dan tahap dessiminate (penyebaran) dengan dibatasi hanya sampai tahap ketiga. Data penelitian ini diperoleh dari angket validasi ahli desain produk, angket validasi ahli kebahasaan, dan angket respon siswa. Jenis data yang dihasilkan adalah data kuantitatif yang dianalisis dengan pedoman kriteria kategori penilaian untuk menentukan kualitas produk. Hasil penelitian ini berdasarkan penilaian ahli desain produk pada draft 1 dengan persentase rata-rata sebesar $81.4 \%$ dengan kategori layak meningkat pada draft 2 menjadi 96\% dengan kategori sangat layak. Hasil penilaian kelayakan bahasa oleh ahli kebahasaan pada draft 1 dengan persentase rata-rata sebesar $68.75 \%$ dengan kategori layak meningkat pada draft 2 menjadi $95 \%$ dengan kategori sangat layak. Berdasarkan hasil respon siswa terhadap buku bergambar yang dikembangkan oleh peneliti diperoleh rata-rata persentase sebesar $94.5 \%$ dengan kategori sangat baik. Hasil penelitian tersebut, maka dapat disimpulkan bahwa produk yang dikembangkan oleh peneliti layak digunakan sebagai sumber belajar pembelajan sastra di Sekolah Dasar.
\end{abstract}

Kata Kunci: buku bergambar, sumber belajar, sekolah dasar

\begin{tabular}{|c|c|c|}
\hline Submitted & Accepted & Published \\
\hline 21 April 2020 & 15 Juni 2020 & 22 Juli 2020 \\
\hline
\end{tabular}

\begin{tabular}{|l|l|l|l|}
\hline Citation & $:$ & $\begin{array}{c}\text { Amalia, S., \& Witri, G. (2020). The Development of Story Book "Ikan Sakti Sungai Janiah" as a Learning Resource of } \\
\text { Literature at Elementary School. Jurnal PAJAR (Pendidikan dan Pengajaran), 4(4), 688-702. DOI : } \\
\text { http://dx.doi.org/10.33578/pir.v4i2.8004. }\end{array}$ \\
\hline
\end{tabular}

\section{PENDAHULUAN}

Pembelajaran sastra merupakan salah satu upaya untuk meningkatkan pendidikan karakter dan minat membaca siswa pada tingkat Sekolah
Dasar. Menurut Pramuki (dalam St. Y Slamet, 2014) sastra anak merupakan karya sastra yang isinya mengenai anak-anak sesuai kehidupan, 
kesenangan, sifat-sifat dan perkembangan anakanak. Hal ini disebabkan karena melalui pembelajaran sastra siswa dapat mengenali dan menggali budaya-budaya nusantara yang sangat beragam. (Warren, 1989) mendefiniskan sastra sebagai sebuah karya imajinatif yang dipandang lebih luas pengertiannya dari pada fiksi.

Sebagai alternatif untuk menanamkan kebiasaan membaca dan menunjang kemandirian siswa salah satunya dengan membuat sumber belajar yang menarik. Sumber belajar yang menarik bagi siswa terutama siswa sekolah dasar adalah sesuatu yang dapat menarik perhatian siswa. Sumber belajar yang mudah di pelajari anak salah satunya adalah dengan menggunakan sumber belajar buku cerita bergambar. Siswa pada usia sekolah dasar cenderung lebih senang membaca jika isi buku terdapat gambar yang menarik, bahkan lebih senang untuk membaca buku cerita bergambar (Rahmawati, 2016). Kalimat yang digunakan dalam buku cerita bergambar juga disesuaikan dengan bahasa anak usia sekolah dasar, yaitu dengan bahasa yang tidak berbelit dan mudah di pahami (Sugiarti, 2015). Buku cerita bergambar adalah buku yang memuat pesan ilustrasi yang berupa gambar dan tulisan. Gambar dan tulisan tersebut membentuk kesatuan yang utuh Rothlein dan Meinbach (dalam Adipta, 2016).

Ahmad (dalam Faizah, 2012) menyebutkan bahwa sumber belajar adalah segala macam sumber yang ada diluar diri seseorang yang dapat memudahkan terjadinya proses belajar. Cerita rakyat diwariskan secara turun-temurun dari generasi ke generasi berikutnya secara lisan (Utomo, 1991). Buku cerita bergambar adalah sebuah cerita ditulis dengan gaya bahasa yang ringan ditambah dengan gambar menjadi kesatuan menyampaikan gagasan tertentu (Faizah, 2009).

Menurut Moeliono (dalam Baharudin, 2016) cerita adalah suatu bentuk tulisan yang dapat menceritakan sebuah peristiwa yang akan terjadi pada waktu tertentu. Buku cerita bergambar merupakan salah satu sumber belajar yang dapat dikembangkan oleh pendidik sebagai media grafis dalam proses pembelajaran Elizabeth Kannedy (dalam Iwan). Cerita rakyat merupakan sebuah karya sastra yang dapat digunakan sebagai sumber belajar untuk membantu siswa mengenali budayabudaya nusantara, yang secara khusus disajikan sebagai sumber pembelajaran dalam bentuk buku cerita. Membaca cerita rakyat merupakan salah satu kegiatan untuk mengembangkan keterampilan sastra di Indonesia (Subriyanto, 2016).

(Wiwin, 2017) mengatakan bahwa cerita rakyat yang sering kali dijadikan acuan dan mengandung suatu nilai luhur mengenai kebaikan, budi pekerti dan lainnya dan dalam pembelajaran sastra di Sekolah Dasar bertujuan untuk melatih siswa dalam berkreasi dengan caranya sendiri, dengan adanya sumber belajar yang menarik menambah minat siswa untuk gemar membaca dan dengan menggunakan buku bergambar menurut (Prasetyono, 2008) mengatakan bahwa sumber belajar yang bergambar (buku bergambar) mempunyai efek lebih kuat dari pada yang tidak bergambar dan melalui sumber belajar yang menarik siswa bisa mempelajari banyak hal, salah satunya adalah pengenalan budaya nusantara melalui cerita rakyat. Melalui cerita rakyat, siswa akan memperoleh pengetahuan mengenai kebudayaan nusantara yang begitu beraneka ragam. (Wahyuningsih, 2012) menyebutkan bahwa minat siswa dapat timbul ketika siswa tertarik dengan sesuatu, dan sesuatu yang dibutuhkan atau dipelajari tersebut dapat bermakna bagi dirinya. Sesuai dengan hakikatnya tersebut, maka pembelajaran sastra bukan hanya sekedar berisi pengetahuan dan teori. Pembelajaran sastra di sekolah dasar juga harus mampu memberi pengalaman pada siswa dengan empat target tujuan pencapaian yaitu: menumbuhkan kesenangan terhadap buku, (2) menginteroretasikan literature, mengembangkan kesadaran bersastra, dan mengembangkan apresiasi (Haryanto, 2013).

Adapun cerita rakyat yang diangkat sebagai sumber belajar untuk pembelajaran sastra di sekolah adalah "Legenda Ikan Sakti Sungai Janiah". Cerita Ikan Sakti Sungai Janiah ini kian menarik di kalangan masyarakat Sumatera Barat sebab mengandung hikmah yang sangat berkaitan dengan kehidupan masyarakat setempat, yang petuah dan amanatnya sangat relevan diimplementasikan sebagai sebuah buku cerita rakyat di tingkat Sekolah Dasar. (Pratama \& 
Marwati, 2016) mengatakan bahwa melalui cerita rakyat inilah pendidikan bisa menanamkan nilainilai kehidupan dengan memberikan cerita rakyat yang memeiliki pesan moral untuk anak-anak. Agar buku cerita rakyat bergambar ini menjadi menarik, maka perlu menerapkan prinsip-prinsip antara lain cerita ditulis dengan keadaan yang sebenarnya, menggunakan kata-kata sederhana dan mudah dipahami anak-anak, serta dilengkapi gambar-gambar isi cerita yang mampu membantu siswa membangun daya imajinasi dan kreativitas berpikir (Hasanah, 2012).

Berdasarkan paparan permasalahan diatas, maka peneliti tertarik untuk melakukan sebuah riset yang berjudul Pengembangan Buku Bergambar Cerita Rakyat "Ikan Sakti Sungai Janiah" Sebagai Sumber Belajar Pembelajaran Sastra di Sekolah Dasar, untuk mengetahui kelayakan buku cerita rakyat dalam pembelajaran sastra, sehingga sehingga dapat menjadi sumber belajar pada siswa di tingkat Sekolah Dasar.

Adapun cerita rakyat yang diangkat sebagai sumber belajar untuk pembelajaran sastra di sekolah adalah "Legenda Ikan Sakti Sungai Janiah". Cerita Ikan Sakti Sungai Janiah ini kian menarik di kalangan masyarakat Sumatera Barat dan pengembangan buku ini menggunakan aplikasi coreldraw7.

\section{METODE PENELITIAN}

Pengembangan buku bergambar cerita rakyat "Ikan Sakti Sungai Janiah" ini menggunakan metode penelitian pengembangan dengan model 4D (Sugiyono, 2019). Model ini terdiri dari empat tahapan, yaitu tahap define, tahap design, tahap develop dan tahap dessiminate. Pada penelitian ini tidak semua tahapan dilakukan, hanya dibatasi pada tiga tahapan, karena peneliti hanya mengembangkan buku cerita bergambar saja untuk mendapatkan nilai kelayakan buku. Tahapan tersebut dapat dilihat pada gambar 1:

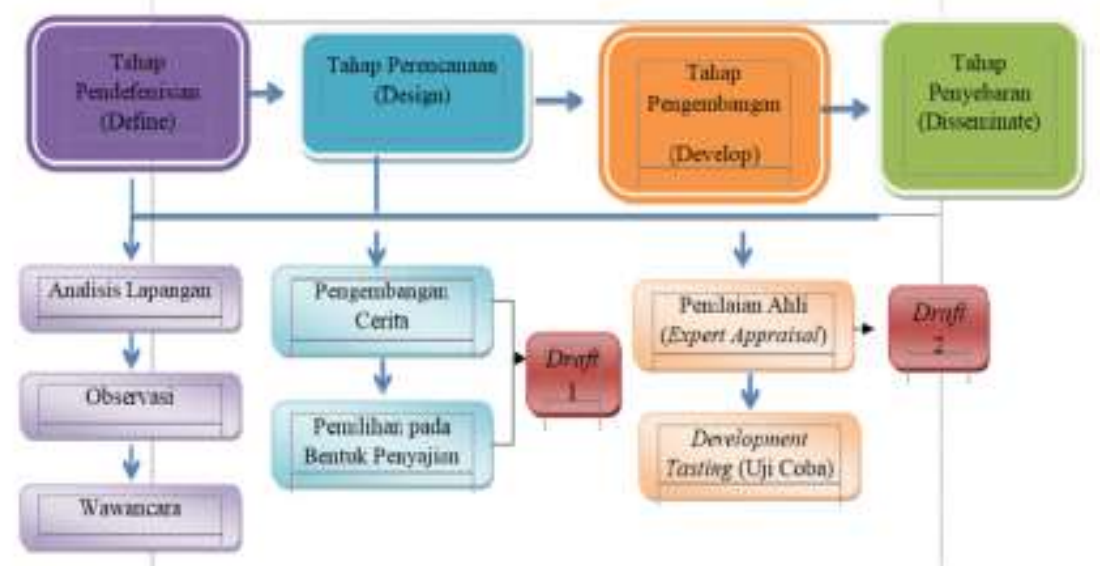

Gambar 1. Tahapan Pelaksanaan Penelitian

Jenis data yang digunakan adalah data kuantitafif berupa skor penilaian yang diberikan oleh validator respon siswa terhadap buku bergambar yang dikembangkan oleh peneliti. Diperlukan 2 orang validator untuk desain produk yaitu dosen ahli desain produk dan praktisi serta 2 orang validator kelayakan bahasa yaitu dosen ahli kebahasaan. Subjek penelitian dalam pelaksanaan ujicoba produk terdiri dari 20 orang siswa. Aspek yang dinilai oleh validator desain produk terdiri dari sampul buku, kesesuaian isi, anatomi buku. Sedangkan aspek yang dinilai dari validator kelayakan kebahasaan adalah isi buku cerita. Untuk angket respon siswa aspek yang dinilai terdiri dari aspek tanggapan dan reaksi terhadap produk yang dikembangkan oleh peneliti.

Kategori penilaian yang akan diberikan oleh validator untuk menilai buku bergambar cerita 
rakyat "Ikan Sakti Sungai Janiah" dapat dilihat pada tabel 1:

Tabel 1. Kategori Penilaian oleh Validator

\begin{tabular}{cc}
\hline Skor Penilaian & Kategori \\
\hline 4 & Sangat Setuju (SS) \\
3 & Setuju (S) \\
2 & Tidak Setuju (TS) \\
1 & Sangat Tidak Setuju (STS) \\
\hline
\end{tabular}

(Sumber: Sugiyono, 2019)

Kriteria dalam mengambil keputusan dalam validasi produk dapat dilihat pada tabel 2 :

Tabel 2. Persentase Kriteria Validitas

\begin{tabular}{cc}
\hline Interval rata - rata skor $(\%)$ & Kategori \\
\hline $76-100$ & Sangat Layak \\
$51-75$ & Layak \\
$26-50$ & Tidak Layak \\
$0-25$ & Sangat Tidak Layak \\
\hline \multicolumn{2}{c}{ Sumber : Sugiyono (2019) }
\end{tabular}

Sedangkan untuk angket respon siswa menggunakan kategori seperti yang terlihat pada tabel 3:

\begin{tabular}{cc}
\multicolumn{2}{c}{ Tabel 3. Kategori Respon Guru dan Respon Siswa } \\
\hline Skor Penilaian & Kategori \\
\hline 4 & Sangat Setuju (SS) \\
3 & Setuju (S) \\
2 & Tidak Setuju (TS) \\
1 & Sangat Tidak Setuju (STS) \\
\hline
\end{tabular}

(Sumber: Sugiyono, 2019)

Kriteria dalam mengambil keputusan pada angket respon guru dan angket respon siswa dapat dilihat pada tabel 4 :

Tabel 4. Persentase Kriteria Penskoran Respon Siswa

\begin{tabular}{cc}
\hline Interval rata - rata skor $(\%)$ & Kategori \\
\hline $76-100$ & Sangat Baik \\
$51-75$ & Baik \\
$26-50$ & Tidak Baik \\
$0-25$ & Sangat Tidak Baik \\
\hline
\end{tabular}

(Sumber: Sugiyono, 2019)

Data validasi oleh validator, aspek validasi yang dinilai oleh validator dibuat dalam bentuk skala penilaian. Jenis skala yang peneliti gunakan adalah Skala Likert. Skala Likert ini memberikan keluasan kepada validator dalam menilai produk 
buku bergambar cerita rakyat "Ikan Sakti Sungai Janiah" yang peneliti kembangkan.

Data angket respon siswa, setelah diperoleh data respon siswa selanjutnya data

\section{HASIL DAN PEMBAHASAN}

\section{Tahap Pendefinisian (Define)}

Sebelum melakukan perancangan produk buku bergambar cerita rakyat "Ikan Sakti Sungai Janiah", hal yang dilakukan adalah melakukan analisis kebutuhan yang berhubungan dengan perancangan produk. Salah satu upaya yang dapat dilakukan guru agar pembelajaran Bahasa Indonesia lebih bermakna adalah dengan penambahan sumber belajar selain buku teks. Penambahan sumber belajar bisa diambil dari buku cerita bergambar.

Buku cerita yang hanya menampilkan tulisan saja tanpa adanya gambar, dapat membuat pembaca dalam hal ini sisiwa sekolah dasar menjadi jenuh dan bosan untuk menyelesaikan bacaan pada buku cerita tersebut. Oleh karena itu buku cerita bergambar dibutuhkan di sekolah dasar karena dengan adanya gambar, pembelajaran tersebut dicari rata-ratanya dengan skor yang telah ditentukan yaitu 1-4

\section{Tabel 5. Bentuk Penyajian}

menjadi lebih menarik, menyenangkan dan mudah dipahami. Sumber belajar yang bervariasi membuat para siswa tertarik dengan buku cerita bergambar, dan dapat membantu mempermudah anak untuk menuangkan gagasan-gagasannya ke dalam bentuk bahasa karena gambar akan memberikan inspirasi dan motivasi yang sangat tinggi kepada siswa untuk melakukan proses pembelajaran.

\section{Tahap Perancangan(Design)}

Dan pada tahap ini hal pertama yang dilakukan pemilihan aplikasi untuk membuat buku bergambar Ikan Sakti Sungai Janiah, yaitu dengan menggunakan aplikasi Coreldraw7. Peneliti memilih aplikasi Coreldraw7 karena dengan menggunakan aplikasi ini akan memudahkan untuk membuat gambar sesuai yang diinginkan.

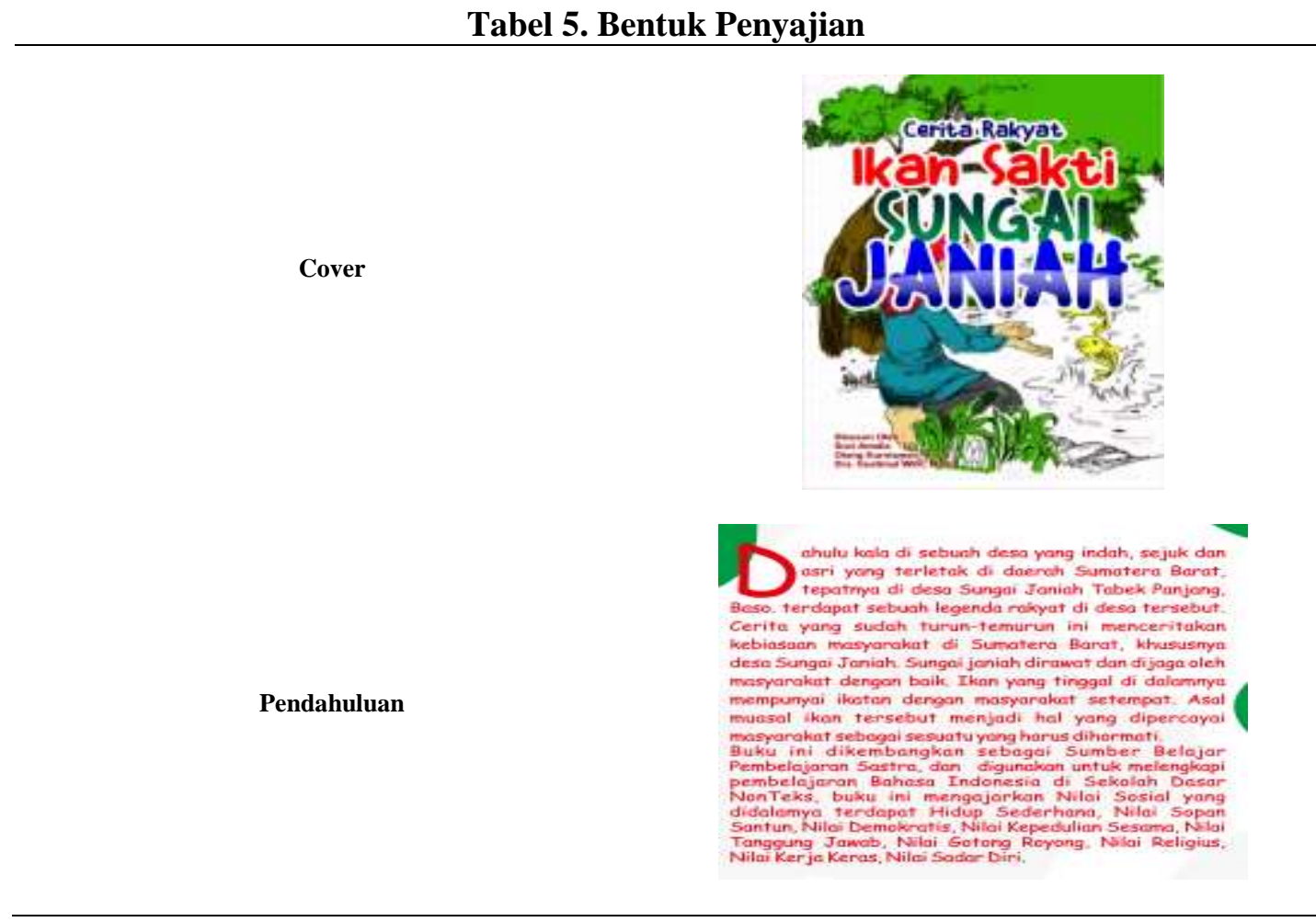


Gambar Awal

Penulisan Cerita Awal

Penutup

\section{Tahap Pengembangan (Develop)}

Pada tahap pengembangan ini juga diperoleh produk akhir buku bergambar cerita rakyat "Ikan Sakti Sungai Janiah". Tahap ini menghasilkan produk yang telah divalidasi dan direvisi berdasarkan masukan dari validator ahli (expert appraisal). Tahap pengembangan dilalui menjadi dua langkah, yaitu:

a. Penilaian Ahli (expert appraisal)

Kegiatan ini dilakukan oleh ahli desain produk yang terdiri dari 1 validator, 1 validator ahli lapangan 2 ahli kebahasaan yang menilai kelayakan buku bergambar "Ikan Sakti Sungai Janiah".

Berikut ini disajikan hasil validasi ahli desain produk yang dikembangkan dan ahli kebahasaan untuk menilai kelayakan cerita yang disajikan dalam bentuk draft 1 dan draft 2 seperti terlihat di bawah ini :

Tabel 6. Hasil Validasi Draft 1 dan Draft 2 Ahli Desain Produk

\begin{tabular}{llllll}
\hline No & Aspek Penilaian & $\begin{array}{l}\text { Rerata Penilaian Ahli } \\
\text { Draft 1 } \\
\text { Persentase }\end{array}$ & Kategori & $\begin{array}{l}\text { Draft 2 } \\
\text { Persentase }\end{array}$ & Kategori \\
\hline 1 & Sampul Buku & $82.5 \%$ & Sangat Layak & $97.5 \%$ & Sangat Layak \\
2 & Kesesuaian isi & $79.2 \%$ & Layak & $91.7 \%$ & Sangat Layak \\
3 & Anatomi Buku & $90.6 \%$ & Sangat Layak & $100 \%$ & Sangat Layak \\
Rerata Kelayakan & $\mathbf{8 1 . 4 \%}$ & Sangat Layak & $\mathbf{9 6 \%}$ & Sangat Layak \\
\hline
\end{tabular}


Dari data kelayakan desain produk buku bergambar "Ikan Sakti Sungai Janiah" draft 1 dan draft 2 di atas, terdapat tiga aspek yang terdiri dari beberapa indikator yang dilakukan penilaian oleh validator. Aspek sampul buku, terdapat lima indikator yang digunakan untuk menilai kelayakan produk yang dikembangkan, pada aspek sampul buku memperoleh presentase skor sebesar $82.5 \%$ pada draft 1 dengan kategori sangat layak dan meningkat pada draft 2 menjadi $97.5 \%$ dengan kategori sangat layak. Berdasarkan data ini memberikan informasi bahwa perancangan produk yang dikembangkan pada aspek ini sesuai dengan karakterisrik sampul pada buku bergambar.

Dalam aspek kesesuaian isi, terdapat tiga indikator yang digunakan untuk menilai kesesuaian isi produk yang dikembangkan, pada aspek kesesuaian isi memperoleh persentase skor sebesar 79.2\% pada draft 1 dengan kategori layak dan meningkat pada draft 2 menjadi $91.7 \%$ dengan kategori sangat layak. Berdasarkan data ini memberikan informasi bahwa perancangan produk ini dapat digunakan oleh siswa sekolah dasar karena gambar dan isi cerita yang dikembangkan saling berhubungan.

Dalam aspek anatomi buku, terdapat 4 indikator yang digunakan untuk menilai anatomi buku yang dikembangkan, pada aspek ini memperoleh persentase skor sebesar $90.6 \%$ pada draft 1 dengan kategori sangat layak dan meningkat pada draft 2 menjadi $100 \%$ dengan kategori sangat layak. Berdasarkan data ini memberikan informasi bahwa perancangan sudah sangat layak digunakan.

Rerata kelayakan produk yang dikembangkan secara keseluruhan pada draft 1 adalah $81.4 \%$ dengan kategori sangat layak dan meningkat pada draft 2 menjadi 96\% dengan kategori sangat layak. Berdasarkan analisis dan informasi dari semua aspek yang dianalisis dan dinilai oleh validator, maka perancangan produk yang dikembangkan, yaitu buku bergambar cerita rakyat "Ikan Sakti Sungai Janiah" sebagai sumber belajar pembelajaran sastra di sekolah dasar, sudah sangat layak digunakan sebagai sumber belajar pembelajaran sastra di sekolah dasar.

Berdasarkan masukan dan penilaian dari tiga validator di atas, maka rancangan produk yang telah dirancang di lakukan perubahan atau perbaikan atas saran dari validator. Berikut ini adalah contoh perubahan atau perbaikan seperti yang terlihat pada tabel 7 di bawah ini:

Tabel 7. Gambar Sebelum dan Sesudah di Validasi

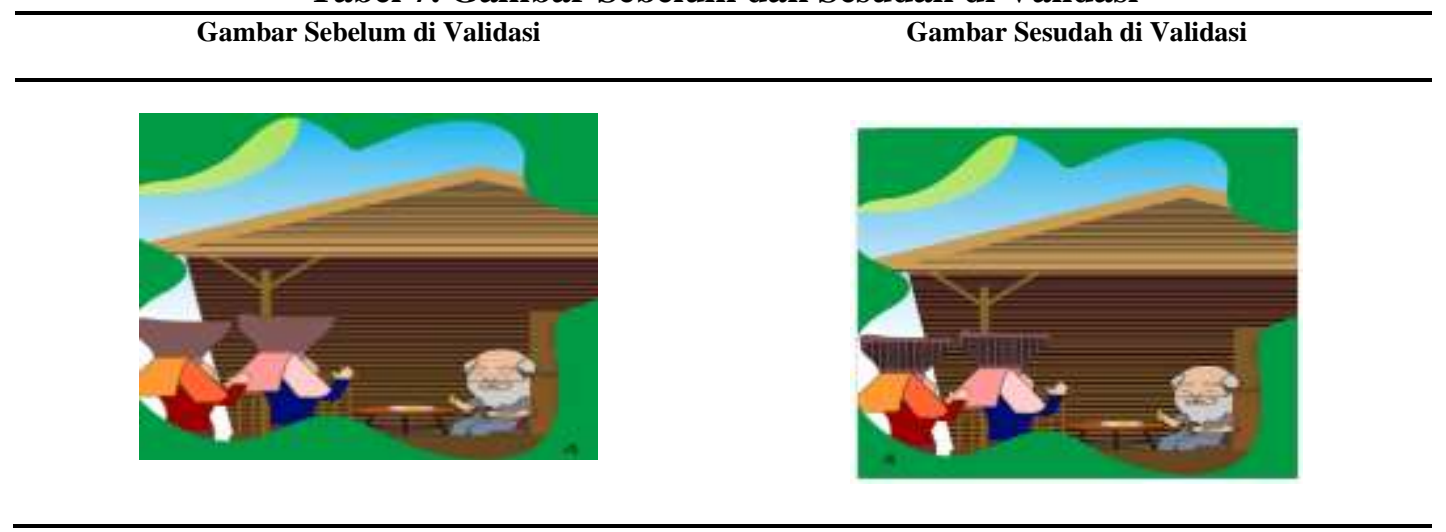



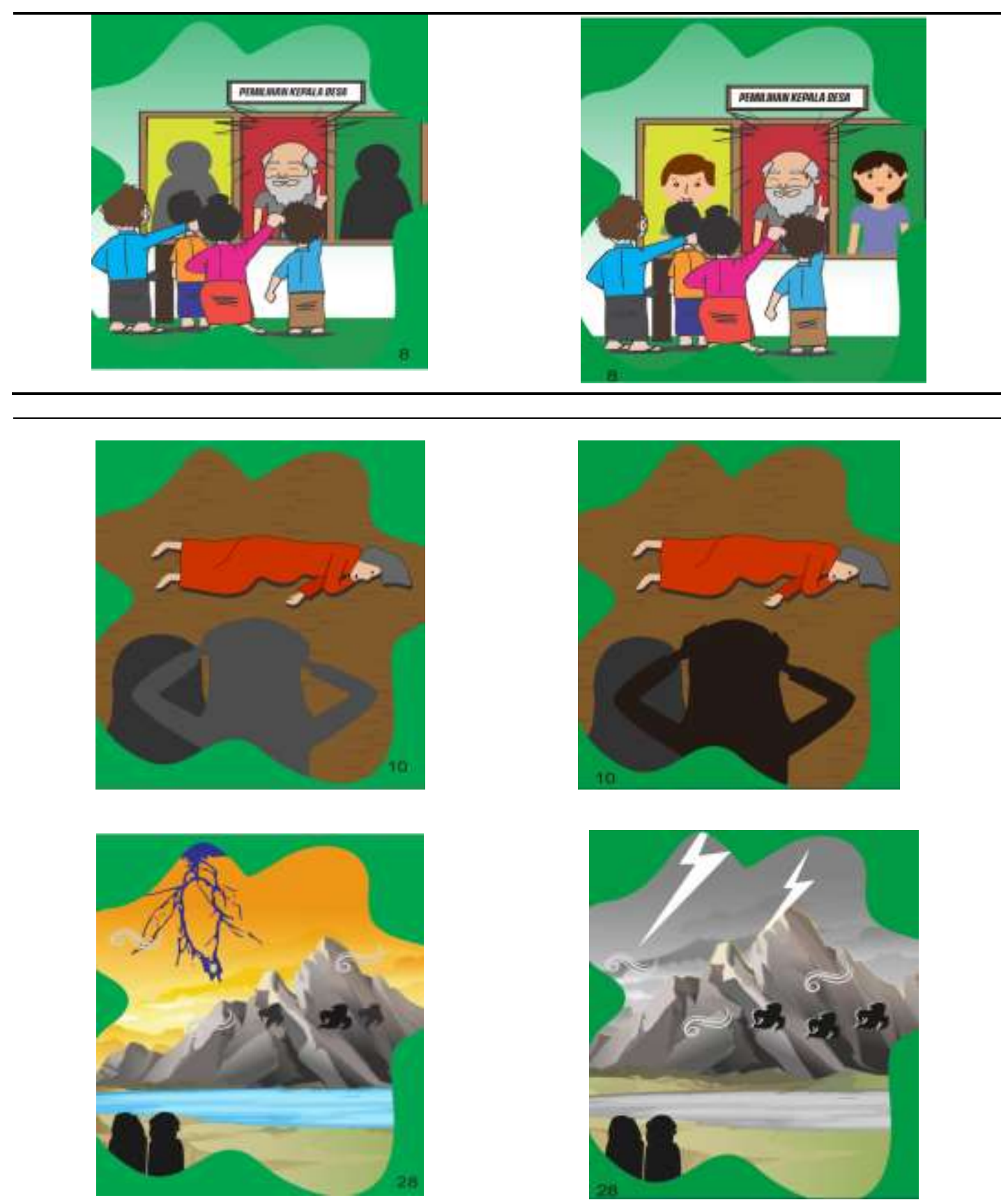

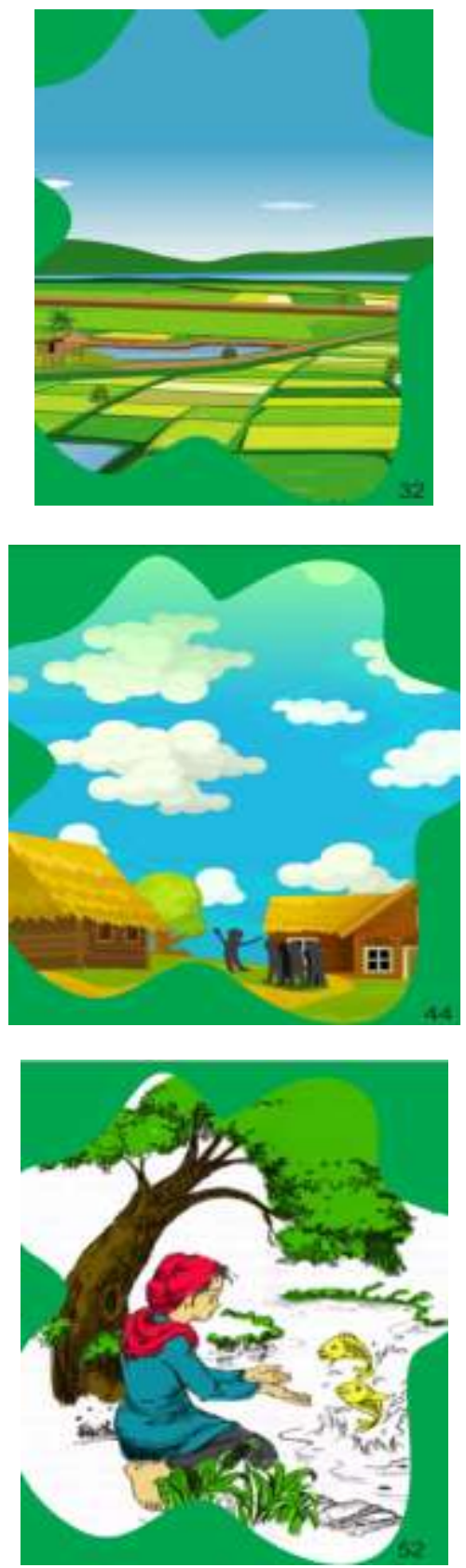
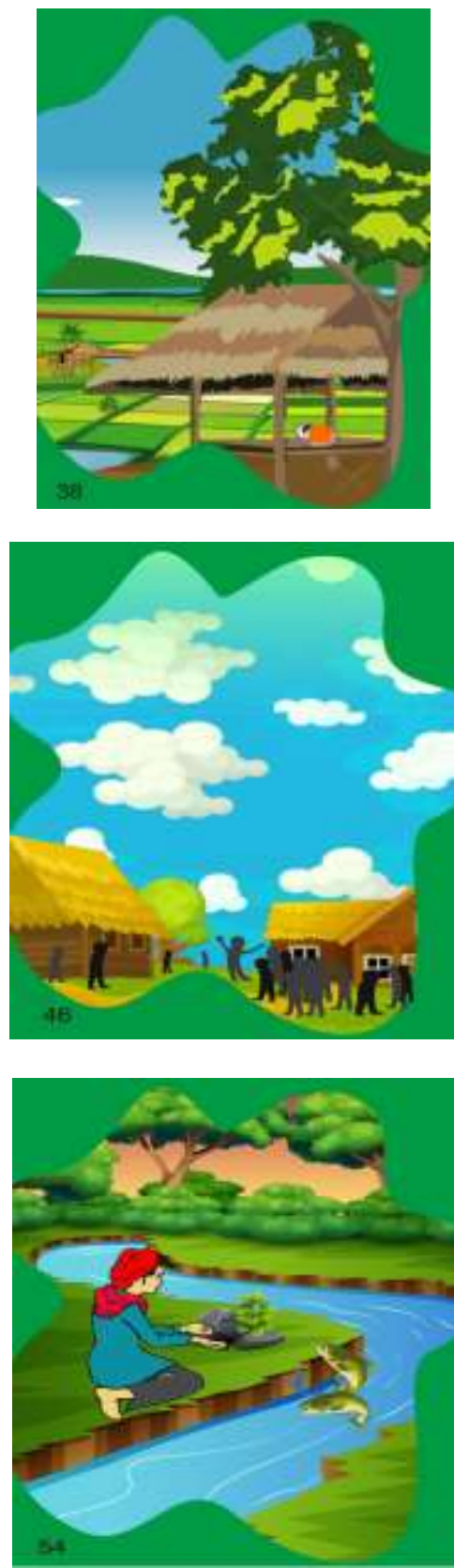

Tabel 8. Hasil Validasi Draft 1 dan Draft 2 Ahli Kebahasaan

\begin{tabular}{lllllll}
\hline No & $\begin{array}{l}\text { Aspek } \\
\text { Penilaian }\end{array}$ & Validator & $\begin{array}{l}\text { Rerata Penilaian Ahli } \\
\text { Draft 1 } \\
\text { Pesentase }\end{array}$ & Kategori & $\begin{array}{l}\text { Draft 2 } \\
\text { Persentase }\end{array}$ & Kategori \\
\hline $\mathbf{1}$ & Isi buku & I & $62.5 \%$ & Layak & $92.5 \%$ & Sangat Layak \\
$\mathbf{2}$ & cerita & II & $75 \%$ & Layak & $97.5 \%$ & Sangat Layak \\
Rerata Kelayakan & & $\mathbf{6 8 . 7 5 \%}$ & Layak & $\mathbf{9 5 \%}$ & Sangat layak \\
\hline
\end{tabular}


Dari data kelayakan kebahasaan cerita yang digunakan pada buku bergambar "Ikan Sakti Sungai Janiah" sebagai sumber belajar pembelajaran sastra di Sekolah Dasar draft 1 dan draft 2 di atas, terdapat satu aspek penilaian yang terdiri dari beberapa indikator yang dilakukan penilaian oleh validator ahli kebahasaan. Aspek isi buku cerita terdapat 10 indikator yang digunakan untuk menilai isi buku cerita, pada aspek ini memperoleh persentase skor sebesar $62.5 \%$ pada draft 1 dengan kategori layak dan meningkat pada draft 2 menjadi $92.5 \%$ dengan kategori sangat layak yang dinilai oleh validator 1 .

Pada aspek ini juga validator 2 menilai kelayakan isi buku cerita dengan memperoleh persentase skor sebesar $75 \%$ pada draft 1 dengan kategori layak dan meningkat pada draft 2 menjadi $97.5 \%$ dengan kategori sangat layak.
Rerata kelayakan isi buku cerita yang digunakan sebagai sumber belajar pembelajaran sastra di Sekolah Dasar secara keseluruhan pada draft 1 adalah $68.75 \%$ dengan kategori layak dan meningkat pada draft 2 menjadi 95\% dengan kategori sangat layak. Berdasarkan analisis dan informasi dari aspek yang dianalisis dan dinilai oleh validator, maka isi cerita buku bergambar "Ikan Sakti Sungai Janiah"sudah sangat layak digunakan sebagai sumber belajar pembelajaran sastra di Sekolah Dasar.

Berdasarkan masukan dan penilaian dari dua validator diatas, maka rancangan produk yang telah dirancang di lakukan perubahan atau perbaikan atas saran dari validator. Berikut ini adalah contoh perubahan atau perbaikan seperti yang terlihat pada tabel 9 di bawah ini:

Tabel 9.Penulisan Sebelum dan Sedudah di Validasi

\begin{tabular}{|c|c|}
\hline Penulisan sebelum di validasi & Penulisan setelah di validasi \\
\hline 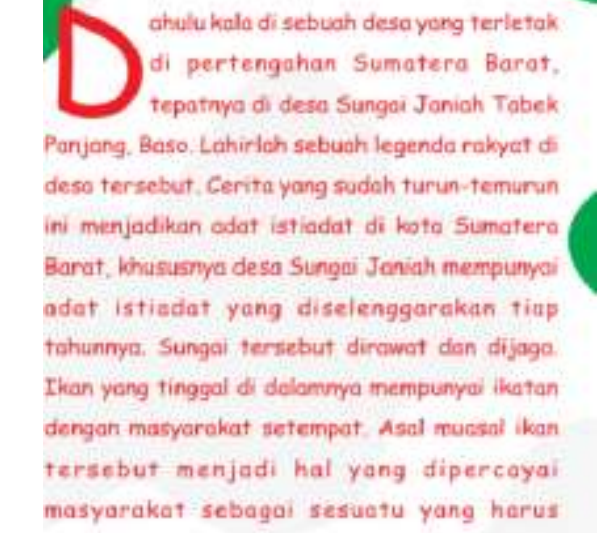 & 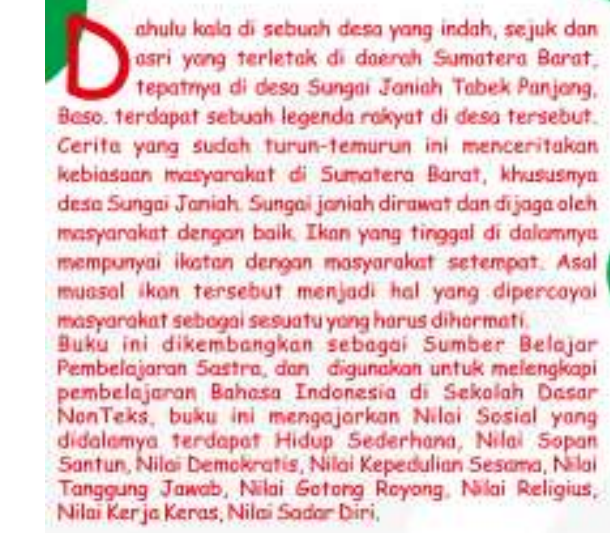 \\
\hline $\begin{array}{l}\text { Pada sebuah halaman rumah } \\
\text { terpencil di atas gunung merapi } \\
\text { Bukit Tinggi. Tampak seorang Laki- } \\
\text { laki tua sedang makan singkong } \\
\text { rebus dengan segelas teh hangat } \\
\text { yang telah terhidang di sebuah meja. } \\
\text { Hal ini biasa dilakukannyadi pagi hari } \\
\text { sambilmenikmatipemandangan. }\end{array}$ & $\begin{array}{l}\text { Di sebuah halaman rumah tampak } \\
\text { seorang laki-laki tua sedang makan } \\
\text { singkong rebus yang telah terhidang } \\
\text { di sebuah meja. Hal ini biasa } \\
\text { dilakukannya di pagi hari sambil } \\
\text { menikmati pemandangan alam yang } \\
\text { sangat indah. }\end{array}$ \\
\hline
\end{tabular}


Jurnal PAJAR (Pendidikan dan Pengajaran)

Volume 4 Nomor 4 Juli 2020 | ISSN Cetak : 2580 - 8435 | ISSN Online : 2614 - 1337

DOI : http://dx.doi.org/10.33578/pir.v4i2.8004

Rombongan ibu-ibu petani yang

sedang memanggul beban di atas kepalanya, lewat di depan rumah lelaki tersebut dan menyapa "Selamat pagi, pak Gigiah". Pak Gigiah, begitulah panggilannya. Nama aslinya adalah Sutan Bosa. Kegigihannya dalam bekerja membuat masyarakat setempat memanggilnya dengan sebutan Pak Gigiah.

"Suamiku, apakah kamu sudah selesai makan?

Seorang wanita menghampiri Pak Gigiah, wanita itu adalah istrinya. Porasnya yong ayu don keibuan membuatnya menjadi salah satu wanita yang dikagumi di desa.

Pok Gigiah tersenyum dan memberi piring kosong bekas makanan yang telah habis dimokan.

- Bapak pergi kerja dulu. Assalammualaikum." Ucap Pak Gigiah pamit meninggalkan istrinya.

Hari ini desa akan mengelar acara pemilitan kepala desa, dengan bermusyawarah. Tetapi, jouh di hari sebelumnya banyak berita yang terdengar dari mulut ke mulut warga desa bahwa pak Gigiah yang akan memenangkan pemilihan kepala desa tersebut, Saat proses pemilihan berlangsung, suara terbanyak dimenangkan oleh Pak Gigiah. Pak Gigiah diangkat menjadi kepala di desa terpencil tersebut.

alah satu warga yang ingin menyampaikan kabar gembira tersebut ingin menjumpai istri Pak Gigiah. Sesampainya di sana. warga tersebut terkejut melihat istri Pak Gigiah yang sudah terbaring pingsan di depan pintu rumahnya. Melihat hal ity warga tersebut berteriak memintd pertolongan kepoda worga lainnya, wargo yang mendengar teriakan minta tolong. make berbondeng-bondonglah warga datang untuk menolong istri Pak Gigiah yang pingsan dalam keadaan hamil dan kemudian warga membawamya ke tempat
Rombongan ibu-ibu petani yang sedang memanggul beban di atas kepalanya, lewat di depan rumah lelaki tersebut dan menyapa "Selamat pagi, pak Gigiah". "Selamat pagi juga, Bu". Pak Gigiah, begitulah panggilanmya. Nama aslinya adalah Sutan Basa. Kegigihannya dalam bekerja membuat masyarakat setempat memanggilnya dengan sebutan Pak Gigiah.

Suamiku, apakah kamu sudah selesai makan?"

Seorang wanita menghampiri Pak Gigiah, wanita itu adalah istrinya. Parasnya yang ayu dan lembut membuatnya menjadi salah satu wanita yang dikagumi di desa.

Pak Gigiah tersenyum dan memberi piring kasong bekas makanan yang telah habis dimakan.

" Sudah istriku bapak pergi kerja dulu. Assalammualaikum." Ucap Pak Gigich pamit meninggalkan istrinya.

Hari ini desa Pak Gigiah akan mengelar acara pemilihan kepala desa, secara bermusyawarah. Jauh hari sebelumnya banyak berita yang terdengar dari mulut ke mulut bahwa Pak Gigiah yang akan memenangkan pemilihan kepala desa tersebut. Saat proses pemilihan berakhir, suara terbanyak dimenangkan oleh Pak Gigiah.

Pak Gigiah pun diangkat menjadi kepala di desa.

Salah satu warga yang ingin menyampaikan kabar gembira tersebut kepada istri Pak Gigiah. Sesampainya di sana, warga tersebut terkejut melihat istri Pak Gigiah yang sudah terbaring pingsan di depan pintu rumahrya. Melihat hal itu wargo tersebut berteriak meminta pertalongar kepada warga lainnya. Warga yang mendengar teriakan minta tolong. berbondong-bondonglah untuk menolong istri Pak Gigiah yang pingsan dalam keadoan hamil, kemudian warga membawanya ke tempat bersalin. 
Jurnal PAJAR (Pendidikan dan Pengajaran)

Volume 4 Nomor 4 Juli 2020 | ISSN Cetak : 2580 - 8435 | ISSN Online : 2614 - 1337

DOI : http://dx.doi.org/10.33578/pir.v4i2.8004

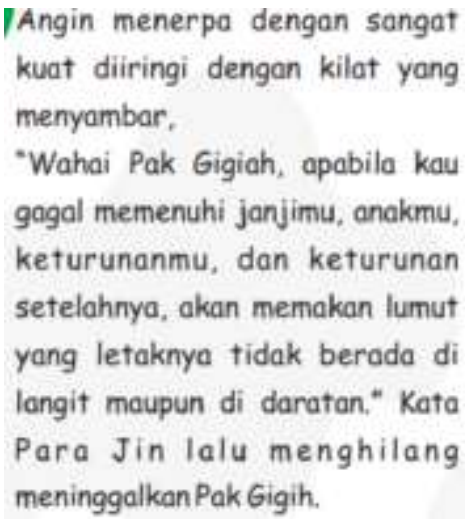

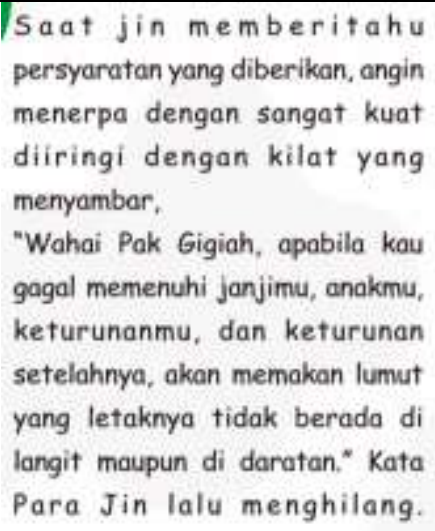

Tujuan dilakukannya revisi penulisan pada buku cerita "Ikan Sakti Sungai Janiah" yang peneliti kembangkan agar dapat di uji cobakan pada skala kecil. Perbaikan yang dilakukan pada isi buku cerita adalah untuk memperbaiki penulisa, dan tanda baca.

a. Uji Coba Terbatas

Pada tahap ini dilakukan ujicoba terbatas untuk memperoleh informasi mengenai respon dari siswa setelah menggunakan rancangan produk yang dikembangkan. Peneliti mengujicoba kan terbatas produk ini buku bergambar "Ikan Sakti Sungai Janiah" pada siswa sekolah dasar khususnya kelas tinggi yang berjumlah 20 orang. Berikut ini adalah data tanggapan dan reaksi siswa pada tabel 10 di bawah ini.

Tabel 10. Data Respon Siswa pada Ujicoba Terbatas

\begin{tabular}{llll}
\hline No & Aspek & Persentase & Kategori \\
\hline 1 & Tanggapan terhadap produk & $92 \%$ & Sangat Baik \\
2. & Reaksi terhadap produk & $97 \%$ & Sangat Baik \\
Rata-rata Persentase & $\mathbf{9 4 . 5 \%}$ & Sangat Baik \\
Tanggapan Siswa & & \\
\hline
\end{tabular}

Berdasarkan hasil data respon siswa terhadap buku bergambar "Ikan Sakti Sungai Janiah" sebagai sumber belajar pembelajaran sastra di Sekolah Dasar yang dikembangkan oleh peneliti diperoleh rata-rata persentase sebesar

\section{PEMBAHASAN}

Berdasarkan maksud dan tujuan penelitian ini digolongkan sebagai penelitian pengembangan (development research) yaitu penelitian yang bermaksud untuk mengembangkan buku bergambar cerita rakyat "Ikan Sakti Sungai Janiah" sebagai sumber belajar pembelajaran sastra di Sekolah Dasar. Selanjutnya tahap define yang berarti pendefinisian. Pada tahap ini yang pertama dilakukan peneliti adalah yaitu analisis kebutuhan. Analisis kebutuhan merupakan
94.5\% dengan kategori sangat baik. Berdasarkan hasil tersebut secara keseluruhan buku bergambar "Ikan Sakti Sungai Janiah" yang dikembangkan oleh peneliti mendapatkan respon yang sangat baik dari siswa yang menggunakan produk ini.

kegiatan yang dilakukan oleh peneliti untuk mengetahui kebutuhan sumber belajar yang dapat digunakan siswa sekolah dasar. Setelah melakukan analisis kebutuhan.

Tahap selanjutnya adalah tahap kedua yaitu tahap design atau perancangan. Tahap design atau perancangan merupakan tahap yang dilakukan untuk merancang produk buku bergambar "Ikan Sakti Sungai Janiah". Pada tahap ini peneliti merancang produk buku bergambar 
"Ikan Sakti Sungai Janiah". Produk yang dihasilkan pada tahap ini disebut draft 1 produk buku bergambar "Ikan Sakti Sungai Janiah".

Tahap ketiga dalam penelitian ini adalah development atau pengembangan. Pada tahap ini peneliti melakukan validasi produk draft 1 kepada 1 orang validator ahli desain produk, 1 validator ahli lapangan, dan 2 orang validator ahli kebahasaan. Setelah melakukan validasi kebeberapa ahli maka diperoleh hasil validasi draft 1. Dari data kelayakan desain produk buku bergambar "Ikan Sakti Sungai Janiah" draft 1 dan draft 2 di atas, terdapat tiga aspek yang terdiri dari beberapa indikator yang dilakukan penilaian oleh validator. Aspek sampul buku, terdapat lima indikator yang digunakan untuk menilai kelayakan produk yang dikembangkan, pada aspek sampul buku memperoleh presentase skor sebesar $82.5 \%$ pada draft 1 dengan kategori sangat layak dan meningkat pada draft 2 menjadi $97.5 \%$ dengan kategori sangat layak. Berdasarkan data ini memberikan informasi bahwa perancangan produk yang dikembangkan pada aspek ini sesuai dengan karakterisrik sampul pada buku bergambar. Pada aspek kesesuaian isi, terdapat tiga indikator yang digunakan untuk menilai kesesuaian isi produk yang dikembangkan, pada aspek kesesuaian isi memperoleh persentase skor sebesar $79.2 \%$ pada draft 1 dengan kategori layak dan meningkat pada draft 2 menjadi $91.7 \%$ dengan kategori sangat layak. Berdasarkan data ini memberikan informasi bahwa perancangan produk ini dapat digunakan oleh siswa sekolah dasar karena gambar dan isi cerita yang dikembangkan saling berhubungan. Pada aspek anatomi buku, terdapat 4 indikator yang digunakan untuk menilai anatomi buku yang dikembangkan, pada aspek ini memperoleh persentase skor sebesar $90.6 \%$ pada draft 1 dengan kategori sangat layak dan meningkat pada draft 2 menjadi $100 \%$ dengan kategori sangat layak. Berdasarkan data ini memberikan informasi bahwa perancangan sudah sangat layak digunakan. Rerata kelayakan produk yang dikembangkan secara keseluruhan pada draft 1 adalah $81.4 \%$ dengan kategori sangat layak dan meningkat pada draft 2 menjadi 96\% dengan kategori sangat layak. Berdasarkan analisis dan informasi dari semua aspek yang dianalisis dan dinilai oleh validator, sangat layak digunakan sebagai sumber belajar pembelajaran sastra di Sekolah Dasar.

Dari data kelayakan kebahasaan cerita yang digunakan pada buku bergambar "Ikan Sakti Sungai Janiah" sebagai sumber belajar pembelajaran sastra di Sekolah Dasar draft 1 dan draft 2 di atas, terdapat satu aspek penilaian yang terdiri dari beberapa indikator yang dilakukan penilaian oleh validator ahli kebahasaan. Aspek isi buku cerita terdapat 10 indikator yang digunakan untuk menilai isi buku cerita, pada aspek ini memperoleh persentase skor sebesar $62.5 \%$ pada draft 1 dengan kategori layak dan meningkat pada draft 2 menjadi $92.5 \%$ dengan kategori sangat layak yang dinilai oleh validator 1 .

Pada aspek ini juga validator 2 menilai kelayakan isi buku cerita dengan memperoleh persentase skor sebesar $75 \%$ pada draft 1 dengan kategori layak dan meningkat pada draft 2 menjadi 97.5\% dengan kategori sangat layak. Rerata kelayakan isi buku cerita yang digunakan sebagai sumber belajar pembelajaran sastra di Sekolah Dasar secara keseluruhan pada draft 1 adalah $68.75 \%$ dengan kategori layak dan meningkat pada draft 2 menjadi 95\% dengan kategori sangat layak. Berdasarkan analisis dan informasi dari aspek yang dianalisis dan dinilai oleh validator, maka isi cerita buku bergambar "Ikan Sakti Sungai Janiah"sudah sangat layak digunakan sebagai sumber belajar pembelajaran sastra di Sekolah Dasar.

Setelah melakukan validasi, tahap selanjutnya adalah melakukan uji coba terbatas untuk mengetahui respon siswa terhadap produk yang dikembangkan oleh peneliti. Uji coba terbatas ini dilakukan pada siswa Sekolah Dasar khususnya kelas tinggi yang berjumlah 20 orang. Berdasarkan hasil data respon siswa terhadap buku bergambar cerita rakyat "Ikan Sakti Sungai Janiah" yang dikembangkan oleh peneliti diperoleh rata-rata persentase $94.5 \%$ dengan kategori sangat baik. Berdasarkan hasil tersebut secara keseluruhan buku bergambar cerita rakyat "Ikan Sakti Sungai Janiah" yang dikembangkan oleh peneliti mendapatkan respon yang sangat baik dari siswa yang menggunakan produk ini. 


\section{SIMPULAN DAN REKOMENDASI}

Buku bergambar cerita rakyat "Ikan Sakti Sungai Janiah" sebagai sumber belajar pembelejaran sastra di sekolah dasar yang dikembangkan oleh peneliti layak digunakan. Kelayakan ini berdasarkan berdasarkan penilaian ahli desain produk pada draft 1 dengan persentase rata-rata sebesar $81.4 \%$ dengan kategori sangat layak meningkat pada draft 2 menjadi 96\% dengan kategori sangat layak. Hasil penilaian kelayakan bahasa oleh ahli kebahasaan pada draft 1 dengan persentase rata-rata sebesar $68.75 \%$ dengan kategori layak meningkat pada draft 2 menjadi 95\% dengan kategori sangat layak. Berdasarkan

\section{DAFTAR PUSTAKA}

Adipta, H, Maryeni, \& Muakibatul. (2016). Pemanfaatan Buku Cerita Bergambar Sebagai Sumber Bacaan Siswa SD. Jurnal Pendidikan , 1(5), 989-992.

Baharudin. (2016). Pengaruh Strategi Paikem dan Minat Baca Terhadap Kemampuan Menulis Cerita Siswa Kelas V SDN 2 Perumnas Way Halim Kec. Kedaton Bandar Lampung Tahun Pelajaran 2010/2011. Terampil: Jurnal Pendidikan dan Pembelajaran Dasar, 3(1), 63-84.

Faizah, U. (2009). Keefektifan Cerita Bergambar untuk Pendidikan Nilai dan Keterampilan Berbahasa dalam Pembelajaran Bahasa Indonesia. Jurnal Cakrawala Pendidikan, 3(3). 249-256.

Hamalik, O. (1994). Media Pendidikan. Bandung: Alumni.

Haryanto, D. (2013). Sastra Anak dalam Pembelajaran di Sekolah Dasar. Jurnal Penelitian Pendidikan, 20.

Hasanah. (2012). Pengembangan Profesi Guru. Bandung: Selemba Empat.

Indiarti, W. (2017). Nilai-Nilai Pembentukan Karakter Dalam Cerita Rakyat Asal Usul Watu Dodol. Jurnal Kajian Sastra, 6(1), 26-41.

Iwan, Y, Dkk. (2014). Perancangan Cerita Bergambar Pentingnya Pengambilan Keputusan yang Bijak. Jurnal Komunikasi Visual Universitas Kristen Petra, 2(5). hasil respon siswa terhadap alat ukur tersebut diperoleh rata-rata persentase sebesar $94.5 \%$ dengan kategori sangat baik.

Saran yang dapat penulis sampaikan adalah: 1) Bagi peneliti; selanjutnya perlu dilakukan penelitian lebih lanjut seperti penelitian analisis buku untuk mendapatkan hasil yang lebih maksimal; 2) Bagi sekolah; Dengan adanya pengembangan buku bergambar cerita rakyat "Ikan Sakti Sungai Janiah" sekolah dapat mengaplikasikan buku ini kedalam pembelajaran sastra di Sekolah Dasar.

Nurgiyantoro, B. (2005). Sastra Anak Pemahaman Dunia Anak. Yokyakarta: Gadjah Mada University Press.

Nurgiyantoro, B. (2010). Teori Pengkajian Fiksi. Yokyakarta: Gadjah Mada University Press.

Prasetyono, D. S. (2008). Rahasia Mengajarkan Gemar Membaca Pada Anak Sejak Dini. Yogyakarta: Diva Press.

Pratama, E. P \& Marwati. (2016). Nilai Pendidikan dalam Cerita Rakyat Tolaki Oheo dan Onggabo. Sulawesi Tenggara. Jurnal Humanika, 1 (16).

Rahmawati, A. (2016). Penerapan SQ3R Berbantuan Reka Cerita Gambar untuk meningkatkan Pemahaman Membaca dan Hasil Belajar Siswa. Profesi Pendidikan Dasar, 3(2), 126-132.

St. Y. Slamet. (2014). Pembelajaran Bahasa dan Sastra Indonesia. Surakarta: UPT UNS Press.

Subriyanto. (2016). Upaya Meningkatkan Kemmapuan Menyimak Cerita Rakyat Siswa Kelas V SDN 16 Air Saleh Kabupaten Banyuasin Melalui Pendekatan Pembelajaran Konstekstual. Jurnal Pembelajaran Bahasa Indonesia dan Sastra Indonesia , 6(1), 1-15.

Sugiarti, D. (2015). Pembuatan Buku Cerita Bergambar Dengan Tokoh Gatotkaca Sebagai Media Pembelajaran Kelas B Tk 
Jurnal PAJAR (Pendidikan dan Pengajaran)

Volume 4 Nomor 4 Juli 2020 | ISSN Cetak : 2580 - 8435 | ISSN Online : 2614 - 1337

DOI : http://dx.doi.org/10.33578/pjr.v4i2.8004

Khalifah Surabaya. Jurnal Pendidikan Seni Rupa. 3(1), 64-69.

Sugiyono. (2019). Metode Penelitian Pendidikan: Kuantitatif, Kualitatif, Kombinasi, $R \& D$, dan Penelitian Pendidikan. Bandung: Alfabeta.

Utomo, S. H. (1991). Mutiara Yang Terlupakan: Pengantar Studi Sastra Lisan. Surabaya: HISKI Jawa Timur.

Warren, R. W. (1989). Teori kesusatraan. Jakarta: Gramedia.

Wahyuningsih, A. N. (2012). Pengembangan Media Komik Bergambar Materi Sistem Saraf Untuk Pembelajaran Yang Menggunakan Strategi PQ4R. Journal of Innovative Science Education, 1(1), 20-27. 